\title{
Synthesis and Properties of Amphiphilic Hyperbranched Poly(dimethylsiloxane) Possessing Hydrophilic Terminal Group
}

\author{
Kyung-Mee KIM, Mitsutoshi JiKeI, and Masa-aki KAKIMOTO ${ }^{\dagger}$ \\ Department of Organic and Polymeric Materials, Tokyo Institute of Technology, \\ Meguro-ku, Tokyo 152-8552, Japan
}

(Received May 13, 2002; Accepted August 26, 2002)

\begin{abstract}
The amphiphilic hyperbranched poly(dimethylsiloxane)(HPDMS) bearing dimethylamine groups on the terminal position was synthesized and characterized. The obtained polymer exhibited low viscosity, and good solubility in ether, THF, and acidic aqueous solution. In the acidic aqueous polymer solution, UV-vis absorption and photo luminescence of water-insoluble chromic compounds such as diphenylhexatriene were measured in order to investigate solvating power of hyperbranched poly(dimethylsiloxane)s. It has turned out from the UV absorbance data that a HPDMS solubilized about five molecules of 1,6-diphenylhexatriene.

KEY WORDS Amphiphilc Polymer / Hyperbranched Polymer/ PDMS / Poly(dimethylsiloxane) / Hydrophilic / Hydrophobic /
\end{abstract}

It is well known that silicon-based polymers, particularly polysiloxanes, have unique properties that lead to a wide range of applications in coatings, adhesives, cosmetics, and surfactants. ${ }^{1-3}$ Thus, the preparation of their hyperbranched analogue is of prime interest from both synthesis and application viewpoints. Recently, a number of hyperbranched poly(siloxysilane)s and hyperbranched poly(alkoxysilane)s have been reported. ${ }^{4-7}$ It has already been reported that siliconcontaining hyperbranched polymers have interesting properties such as thermal stability, good solubility, lower viscosity, and the possibility to introduce many kinds of substituents, in comparison with linear polysiloxanes. ${ }^{8-17}$

Amphiphilic dendritic molecules can form unimolecular micelles, which are different from conventional ones formed by intermolecular aggregation. The unimolecular micelles could show enhanced thermodynamic stability and might achieve stable encapsulation of small molecules. In addition polymeric micelles composed of body adaptable silicon materials have recently emerged as promising carriers for drug-delivery system. ${ }^{18}$ Due to hydrophobic nature of siloxane structure, the introduction of hydrophilic fragments, such as hydroxyl and amino groups at the terminal position could give a novel water-soluble hyperbranched polysiloxane. It should be expected to encapsulate hydrophobic compounds to make them water-soluble, as micelles do. ${ }^{19,20}$ These unique properties may enable a wide variety of macromolecules applications in the areas of molecular encapsulation, membrane transport, and catalysis. $^{21-23}$

We recently reported the synthesis and properties

${ }^{\dagger}$ To whom correspondence should be addressed. of hyperbranched poly(dimethylsiloxane)s (HPDMSs) from a novel $\mathrm{AB}_{2}$ type monomer, bis(dimethyldiethylaminosiloxy)methylsiloxydimethylsilanol. ${ }^{24}$

The HPDMS end-capped with dimethylphenylsilanol (DMPS) showed unique photo-degradable property, which might be useful for photo-resist applications.

In this work, we describe the preparation and properties of hyperbranched poly(dimethylsiloxane) (HPDMS) end-capped with bis(3-( $N, N$-dimethylamino)propyl)methylsilylphenyldimethylsilanol as hydrophilic substituent. The resulting HPDMS is expected to show amphiphilicity induced by the chemical structure: hydrophobic dimethylsiloxy chains and hydrophilic dimethylamine terminal groups. The encapsulation of hydrophobic compounds by the HPDMS in the acidic aqueous solution was also investigated.

\section{EXPERIMENTAL}

\section{Measurement}

${ }^{1} \mathrm{H},{ }^{13} \mathrm{C}$ NMR and ${ }^{29} \mathrm{Si}$ NMR measurements were carried out by a JEOL JNM-AL $300 \mathrm{MHz}$ spectrometer in $\mathrm{CDCl}_{3}$ without TMS. Infrared spectra were obtained using a Shimadzu FT-IR 8100 Fourier transform infrared spectrophotometer and photoluminescence spectra were obtained by using a OTSUKA MCPD 1000. Vapor pressure osmometer (VPO) measurements were performed in benzene using a Corona Electric VPO at $40^{\circ} \mathrm{C}$. Gel permeation chromatography measurements were performed in THF as the eluent with a JASCO HPLC 880PU, and a Shodex KF-802.5 column. Thermo gravimetric analysis (TGA) and differential scanning calorimetry (DSC) were carried out with a Seiko TGA 6200 and a Seiko DSC 6200 with a heat- 
ing rate of $10{ }^{\circ} \mathrm{C} \mathrm{min}^{-1}$ under $\mathrm{N}_{2}$. Inherent viscosity, $\eta_{\text {inh }}$, was measured in THF at $30^{\circ} \mathrm{C}$ at a concentration of $0.5 \mathrm{~g} \mathrm{dL}^{-1}$.

\section{Materials.}

Bis(dimethylphenylsiloxy) methylsiloxydimethylsilanol as an $\mathrm{AB}_{2}$ type monomer precursor was prepared from dichlorosilane and diethylamine, as reported in our previous work. $^{24}$ Dimethylaminopropylchloride and dibromobezene were purified by distillation and recrystallization. Trichloromethylsilane was purchased from Aldrich chemical company and used without further purification. The solvents such as THF, ether and hexane were dried by distillation over sodium benzophenone ketyl and $\mathrm{CCl}_{4}$ was distilled over $\mathrm{CaCl}_{2}$.

\section{4-Bromophenyldichloromethylsilane (2)}

A $500 \mathrm{~mL}$ round-bottom flask equipped with a septum, and a gas-inlet needle was charged with $47.2 \mathrm{~g}$ $(0.2 \mathrm{~mol})$ of $p$-dibromobenzene, $5.1 \mathrm{~g}(0.21 \mathrm{~mol})$ of magnesium and $400 \mathrm{~mL}$ of THF. After stirring at $25^{\circ} \mathrm{C}$ for $2 \mathrm{~h}$, the mixture was cooled by an ice bath. And methyltrichlorosilane $29.90 \mathrm{~g}(0.20 \mathrm{~mol})$ was added slowly via syringe, and the mixture was stirred for an additional $4 \mathrm{~h}$. The precipitate formed during the reaction was removed by filtration under nitrogen. Most of the volatiles were removed using a rotary evaporator to give a clear yellow solution. Further purification of the crude product by fractional distillation gave 4bromophenyldichloromethylsilane $\mathbf{2}$ as a clear colorless liquid in $48 \%$ yield $(25.9 \mathrm{~g})$ bp $59-62{ }^{\circ} \mathrm{C} / 0.1$ Torr. ${ }^{1} \mathrm{H}$ NMR $\left(\mathrm{CDCl}_{3}, \delta \mathrm{ppm}\right), 7.43$ (m, 4H), 0.89 (s, 3H).

\section{4-Bromophenylbis(3-N,N-dimethylaminopropyl)meth- ylsilane (3)}

A $1 \mathrm{~L}$ round-bottom flask equipped with a septum, and a gas inlet needle was charged with $25.5 \mathrm{~g}$ $(0.21 \mathrm{~mol})$ of $3-N, N$-dimethylaminopropyl chloride, $5.1 \mathrm{~g}(0.21 \mathrm{~mol})$ of magnesium, $500 \mathrm{~mL}$ of THF, and the several drops of ethylene bromide as a catalyst. After stirring for $1 \mathrm{~h}$, to the solution of the mixture was added dropwise $25.9 \mathrm{~g}(0.1 \mathrm{~mol})$ of 2 in THF $(150 \mathrm{~mL})$ and stirred for $8 \mathrm{~h}$ at $25^{\circ} \mathrm{C}$. After the precipitated magnesium chloride was removed by filtration and the solvent in the filtrate was evaporated. Reduced distillation of the crude mixture provided 4-bromophenylbis(3- $N, N$ dimethylaminopropyl)methylsilane $\mathbf{3}$ as a clear, colorless liquid in $76 \%$ yield $(22.3 \mathrm{~g})$ bp $131-135^{\circ} \mathrm{C} / 0.1$ Torr. ${ }^{1} \mathrm{H}$ NMR $\left(\mathrm{CDCl}_{3}, \delta\right.$ ppm), $7.58(\mathrm{~m}, 4 \mathrm{H}, \mathrm{Ph}), 2.41$ $\left(\mathrm{t}, 4 \mathrm{H}, \mathrm{CH}_{2}\right), 2.35\left(\mathrm{~s}, 12 \mathrm{H}, \mathrm{CH}_{3}\right), 1.61\left(\mathrm{~m}, 4 \mathrm{H}, \mathrm{CH}_{2}\right), 0.95$ $\left(\mathrm{m}, 4 \mathrm{H}, \mathrm{CH}_{2}\right), 0.51\left(\mathrm{~s}, 3 \mathrm{H}, \mathrm{SiCH}_{3}\right)$.
4-Bis(3-N,N-dimethylaminopropyl)methylsilylphenyldimethyl-N,N-diethyl-aminosilane (4)

4-Bis(3- $N, N$-dimethylaminopropyl)methylsilylphenyllithium was prepared from $22.3 \mathrm{~g}(0.06 \mathrm{~mol})$ of $\mathbf{3}$ and $38 \mathrm{~mL}$ of butyllithium solution (1.6 M in hexane) in $200 \mathrm{~mL}$. To the solution, $10 \mathrm{~g}(0.06 \mathrm{~mol})$ of $N, N$ diethylaminodimethylchlorosilane in $100 \mathrm{~mL}$ of ether was added at room temperature. After the mixture was stirred for $8 \mathrm{~h}$, the precipitated lithium chloride was removed by filtration under nitrogen. Reduced distillation of the crude product gave a pure 4-bis(3-N,Ndimethylaminopropyl)methylsilylphenyldimethyl- $N, N$ diethylaminosilane $\mathbf{4}$ as a clear colorless liquid in $79 \%$ yield $(20.0 \mathrm{~g})$ bp $152-155^{\circ} \mathrm{C} / 0.1$ Torr. ${ }^{1} \mathrm{H}$ NMR $\left(\mathrm{CDCl}_{3}, \delta \mathrm{ppm}\right), 7.73(\mathrm{~m}, 4 \mathrm{H}, \mathrm{Ph}), 3.20\left(\mathrm{q}, 4 \mathrm{H}, \mathrm{CH}_{2}\right)$, $2.41\left(\mathrm{t}, 4 \mathrm{H}, \mathrm{CH}_{2}\right), 2.35\left(\mathrm{~s}, 12 \mathrm{H}, \mathrm{CH}_{3}\right), 1.61\left(\mathrm{~m}, 4 \mathrm{H}, \mathrm{CH}_{2}\right)$, $1.26\left(\mathrm{t}, 6 \mathrm{H}, \mathrm{CH}_{3}\right), 0.95\left(\mathrm{~m}, 4 \mathrm{H}, \mathrm{CH}_{2}\right), 0.58\left(\mathrm{~s}, 6 \mathrm{H}, \mathrm{CH}_{3}\right)$, $0.51\left(\mathrm{~s}, 3 \mathrm{H}, \mathrm{CH}_{3}\right)$.

\section{4-Bis(3-N,N-dimethylaminopropyl)methylsilylphenyl- dimethylsilanol (5)}

A $250 \mathrm{~mL}$ Schlenk three-necked flask equipped with a septum, and a gas inlet tube was charged with $150 \mathrm{~mL}$ of distilled water, and $20.0 \mathrm{~g}(0.05 \mathrm{~mol})$ of 4 was added by dropping funnel at $25^{\circ} \mathrm{C}$. The mixture was stirring for $30 \mathrm{~min}$ and the organic layer was separated. The organic layer was dried over $\mathrm{Mg}_{2} \mathrm{SO}_{4}$ and filtered. Most of the volatiles were removed using a rotary evaporator. The crude product was further purified by distillation and a pure 4-bis $(3-N, N$ dimethylaminopropyl)methylsilylphenyldimethylsilanol 5 was obtained as a clear colorless liquid in $65 \%$ yield. ( $11.9 \mathrm{~g}$ bp $153-155{ }^{\circ} \mathrm{C} / 0.1$ Torr) ${ }^{1} \mathrm{H}$ NMR $\left(\mathrm{CDCl}_{3}, \delta \mathrm{ppm}\right), 7.73(\mathrm{~m}, 4 \mathrm{H}, \mathrm{Ph}), 2.55\left(\mathrm{q}, 4 \mathrm{H}, \mathrm{CH}_{2}\right)$, $2.41\left(\mathrm{~s}, 12 \mathrm{H}, \mathrm{CH}_{3}\right), 1.68\left(\mathrm{~m}, 4 \mathrm{H}, \mathrm{CH}_{2}\right), 0.98\left(\mathrm{~m}, 4 \mathrm{H}, \mathrm{CH}_{2}\right)$, $0.58\left(\mathrm{~s}, 6 \mathrm{H}, \mathrm{CH}_{3}\right), 0.51\left(\mathrm{~s}, 3 \mathrm{H}, \mathrm{CH}_{3}\right),{ }^{13} \mathrm{C} \mathrm{NMR}\left(\mathrm{CDCl}_{3}\right.$, $\delta \mathrm{ppm}), 135.2,133.4,129.9,122.7,63.1,45.4,21.9$, $11.5,0.35,-5.1 \mathrm{IR}\left(\right.$ neat, $\left.\mathrm{cm}^{-1}\right) ; 3074,2905,1472$, $1259,1118,1026,831,790,700$.

\section{Preparation of End-capped HPDMS with 5}

From the $\mathrm{AB}_{2}$ monomer precursor, bis(phenyldimethylsiloxy)methylsiloxydimethylsilanol, to polymerization, mixture was carried out by the method previously reported. ${ }^{24}$ Into the mixture, $11.5 \mathrm{~g}(0.031 \mathrm{~mol})$ of 5 was added and refluxed for $24 \mathrm{~h}$. The mixture was diluted with $200 \mathrm{~mL}$ of ether and washed with $200 \mathrm{~mL}$ of water. The organic layer was extracted and dried over anhydrous magnesium sulfate. The end-capped HPDMS was obtained by precipitation from THF into hexane. Yield $82 \%,{ }^{1} \mathrm{H}$ NMR $\left(\mathrm{CDCl}_{3}, \delta \mathrm{ppm}\right), 7.73$ (m), $7.50(\mathrm{~m}), 2.62(\mathrm{~m}), 2.44$ (b), $1.70(\mathrm{~m}), 1.02$ (m), 0.62 (m), 0.34 (b), 0.15 (b), 0.07 (b), ${ }^{13} \mathrm{C}$ NMR 

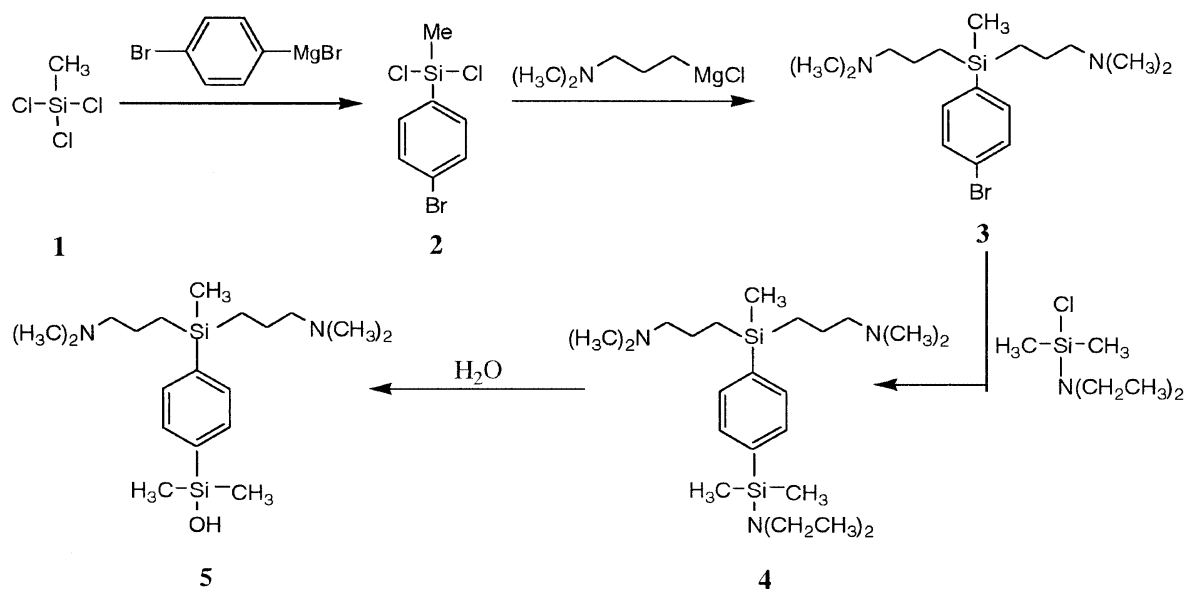

Scheme 1.

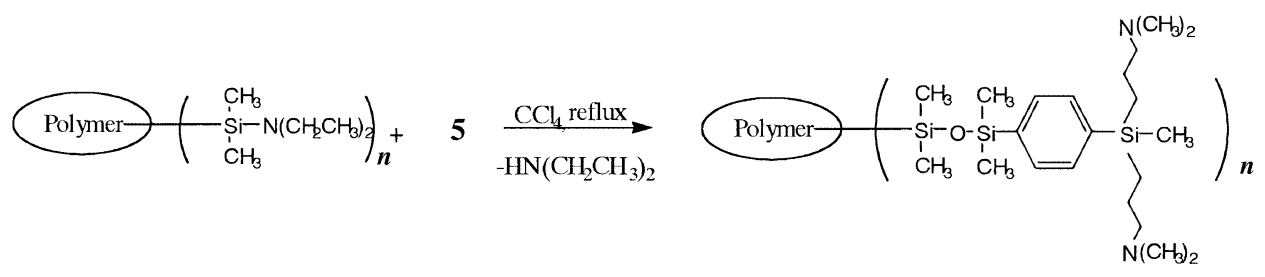

Scheme 2. Synthesis of endcapping hyperbranched poly(dimethylsiloxane)s with $\mathbf{5}$.

$\left(\mathrm{CDCl}_{3}, \delta \mathrm{ppm}\right), 135.2,133.4,133.0,129.9,129.2$, $127.5,122.7,63.1,45.4,21.9,11.5,0.60,0.35,-2.7$, $-3.0,-5.1$, IR (neat, $\mathrm{cm}^{-1}$ ); 3070, 2905, 1472, 1400, 1259, 1179, 1026, 700, Elemental Anal. Calcd. for $\mathrm{C}_{78} \mathrm{H}_{174} \mathrm{O}_{15} \mathrm{~N}_{6} \mathrm{Si}_{18}: \mathrm{C}, 48.24 ; \mathrm{H}, 9.03 ; \mathrm{O}, 12.36 ; \mathrm{N}, 4.32$. Found $\mathrm{C}, 47.01 ; \mathrm{H}, 8.95 ; \mathrm{O}, 11.07 ; \mathrm{N}, 4.01$.

\section{Sample Preparation and UV-vis Measurements.}

Typical experimental procedures are described as follows. The HPDMS $\left(1.3 \times 10^{-6} \mathrm{~mol}\right)$ was prepared with $4.5 \mathrm{mg}$ of the obtained hyperbranched polymer in the $200 \mathrm{~mL}$ of $0.1 \mathrm{M}$ hydrochloric acidic aqueous solution. 1,6-Diphenylhexatriene $\left(1.3 \times 10^{-5} \mathrm{~mol}(3.5 \mathrm{mg})\right)$ was added to the HPDMS acidic aqueous solution. The solution was stirred for $2 \mathrm{~h}$ at room temperature. And the solution was filtered with a $0.2 \mu \mathrm{m}$ filter to remove insoluble part. UV-vis measurements for the filtrate were carried out in order to determine the dissolved amount of 1,6-Diphenylhexatriene.

\section{RESULTS AND DISCUSSION}

The endcapping agent 5 containing dimethylamino groups was prepared as shown in Scheme $1 .^{20} 4-$ Bromophenylmagnesium bromide was reacted with trichloromethylsilane $\mathbf{1}$ to form dichloromethylbromophenylsilane $\mathbf{2}$. The compound $\mathbf{3}$ was prepared by the condensation reaction of $\mathbf{2}$ with two equivalent of 3-(N,N-dimethylamino)propylmagnesium chloride. $\mathrm{N}, \mathrm{N}$-Diethylaminodimethylchlorosilane was reacted with lithiated 3 to form the compound 4 . The final silanol compound $\mathbf{5}$ was prepared by the hydrolysis of the compound 4 . The end-capping agent 5 was obtained in yield of $19 \%$ based on the starting compound 2. Hyperbranched polydimethylsiloxane(HPDMS) was prepared from an $\mathrm{AB}_{2}$ type monomer, bis(dimethyl$N, N$-diethylaminosiloxy)methylsiloxydimethylsilanol, as described in our previous report. ${ }^{24}$ The end-capped HPDMS which has 0.49 of degee of branching was prepared by the reaction with silanol group of $\mathbf{5}$ and amino end groups of the original HPDMS, as shown in Scheme 2. The HPDMS end-capped with $\mathbf{5}$ was a sticky solid at room temperature. Table I summarizes the properties of HPDMSs end-capped with compound 5 and with DMPS. Number average molecular weight $\left(M_{\mathrm{n}}\right)$ of the resulting HPDMS determined by VPO with benzene eluent were 9980, and the VPO data was comparable with the previous work. ${ }^{24}$ From the molecular weight and ${ }^{1} \mathrm{H}$ NMR spectrum, we understood imperfection substitution of the HPDMS with compound 5. Figure 1 displays the ${ }^{1} \mathrm{H}$ NMR spectrum of the HPDMS end-capped with compound 5. The peaks at $\delta 7.58$ and $0.05-0.15 \mathrm{ppm}$, correspond to the phenyl groups in the compound $\mathbf{5}$ and dimethyl groups adjacent to the silicon atom, respectively. The integration ratio of the two peaks ( $\mathrm{f}: \mathrm{i}$ ) was calculated as $6.2: 1$, which agree with the ratio $20: 13$ of $\mathrm{AB}_{2}$ monomer : compound $\mathbf{5}$ in the HPDMS in the case of 9980 molecular weight. As the similar ratio of 21.6: 12.6 was obtained by the element analysis, 
Table I. Properties of HPDMS endcapped with $\mathbf{5}$ compared with HPDMS ${ }_{\mathrm{DMPS}}$

\begin{tabular}{|c|c|c|}
\hline & $\left(\begin{array}{cc}\mathrm{CH}_{3} & \mathrm{CH}_{3} \\
1 & \mathrm{~S} i-\mathrm{O}-\mathrm{Si}_{3}- \\
1 & 1 \\
\mathrm{CH}_{3} & \mathrm{CH}_{3}\end{array}\right.$ & $\mathrm{H}_{3} \quad \mathrm{CH}_{3}$ \\
\hline Physical state & bright yellow sticky solid & yellow elastic solid \\
\hline $\begin{array}{l}\text { Molecular } \\
\text { weight }\end{array}$ & $M_{\mathrm{n}}=9980$ & $M_{\mathrm{n}}=9800$ \\
\hline$T_{\mathrm{g}}^{\mathrm{b}}$ & $199 \mathrm{~K}$ & $181 \mathrm{~K}$ \\
\hline Solubility & $\begin{array}{l}\text { very soluble in toluene, ether, THF, } \\
\text { and ethanol, water }\end{array}$ & toluene, ether, very soluble in THF \\
\hline $\mathrm{TGA}^{\mathrm{c}}$ & $\begin{array}{l}\text { onset decompose at } 178^{\circ} \mathrm{C} \\
T_{10}\left(267^{\circ} \mathrm{C}\right)\end{array}$ & $\begin{array}{l}\text { onset decompose at } 192^{\circ} \mathrm{C} \\
T_{10}\left(289^{\circ} \mathrm{C}\right)\end{array}$ \\
\hline
\end{tabular}

${ }^{\text {a }}$ Determinded by VPO with benzene eluent at $40^{\circ} \mathrm{C}$. ${ }^{b}$ Determinded by DSC at a heating rate of $10^{\circ} \mathrm{Cmin}^{-1}$ in nitrogen on second heating. ${ }^{\mathrm{c}}$ Temperature at which the polymer sample has lost its original mass ${ }^{\mathrm{d}}$ End-capped HPDMS with dimethylphenylsilanol prepared at previous report. ${ }^{24}$

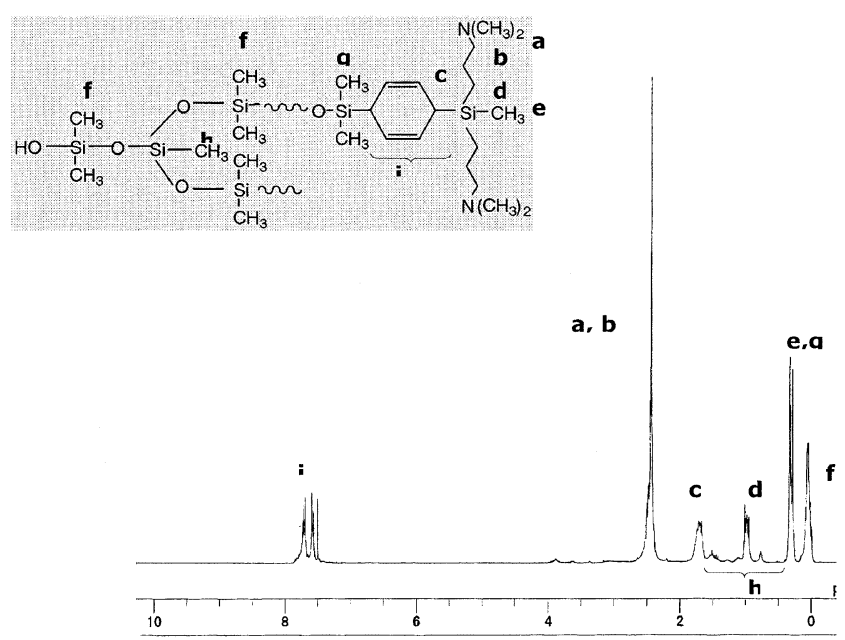

Figure 1. ${ }^{1} \mathrm{H}$ NMR spectrum of HPDMS end-capped with compound $\mathbf{5}$.

$\mathrm{C} / \mathrm{N}(11.8: 1)$, the average ratio of the monomer and end-capping group for HPDMS was calculated as $20: 13$, which is not enough to ideal ratio of $20: 21$.

The end-capped hyperbranched polymer showed good solubility in many organic solvents, such as toluene, ether, THF and methanol. It is interesting to note that the polymer was also readily soluble in acidic aqueous solution. $T_{\mathrm{g}}$ of the HPDMS end-capped by $\mathbf{5}$ was $199 \mathrm{~K}$, and higher in comparison with the polymer end-capped by DMPS. However the onset temperature for thermal decomposition was lowered to $178^{\circ} \mathrm{C}$.

The end-capped HPDMS can be recognized as an amphiphilic polymer. The encapsulation of hydrophobic molecules by the end-capped HPDMS in acidic aqueous solution was investigated by UV-vis absorption. 1,6-Diphenylhexatriene, 3,5dinitrochlorobenzene and p-nitrotoluene were exam- ined as hydrophobic chromophores, which have been used in the siloxane dendrimer. ${ }^{20}$ A large amount of the chromophore was fed to HPDMS acidic solution, and then, insoluble part was removed by filtration to prepare saturated solution. As shown in Figure 2, the absorption peaks of the chromophores were observed, whereas no absorption of the chromophores was observed in the absence of the HPDMS. The fact clearly indicates the successful encapsulation of the dye molecules by the HPDMS. Figure 2 also showed that the peak intensity of the chromic compounds increased in proportion to the concentration of HPDMS.

The molar concentration(c) of the chromic compounds encapsulated by the HPDMS can be calculated from the peak intensity as follows;

$$
\mathbf{c}=\mathbf{A} / \varepsilon \mathbf{b}
$$

where $\mathbf{A}, \mathbf{b}$, and $\varepsilon$ represent absorbance, the thickness $(\mathrm{cm})$ of the cell used, and molar absorption coefficient, respectively. All of the $\varepsilon$ values were calculated by the measurements of THF solution since the chromic compounds are insoluble in water. The data for the calculation are summarized in Table II. The " $\boldsymbol{n}$ " in Table II represents the number of chromic compounds if they were encapsulated in one HPDMS molecule. It was found that several dye molecules were encapsulated in the HPDMS molecule in aqueous acidic solution. In the case of 1,6-diphenylhexatriene (Figure 3), " $n$ "s were independent on the concentration of HPDMS. The same trend was also observed for p-nitrotoluene. The $\boldsymbol{n}$ for 1-chloro-2,4-dinitrobenzene was slightly lowered by increasing the concentration of HPDMS. The encapsulation number of 1,6-diphenylhexatriene was very less than other two compounds, which are inferred that 

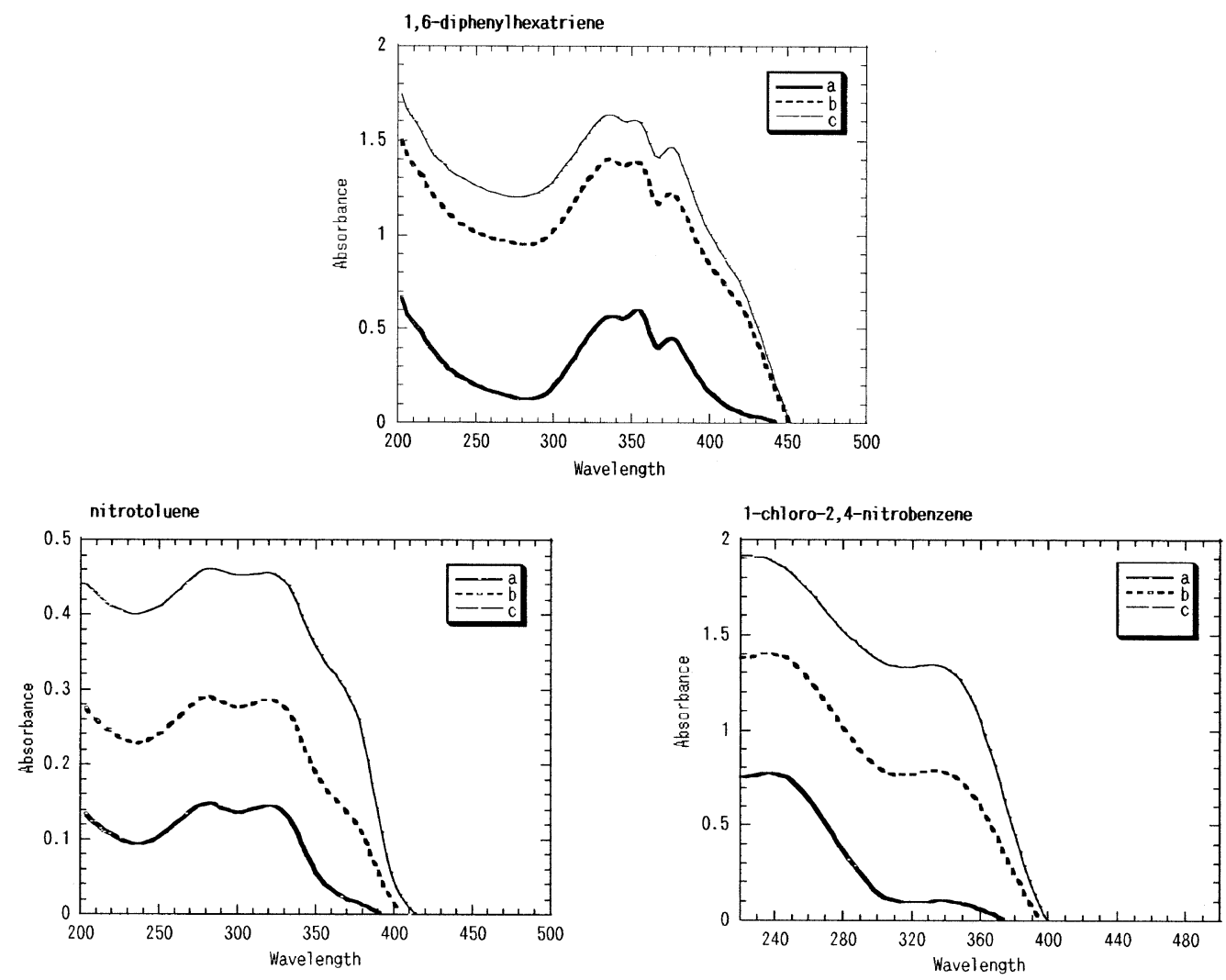

Figure 2. UV-vis absorption spectra of chromic compounds in the polymer acidic aqueous solution $\left(\mathbf{a}: 1.3 \times 10^{-6}, \mathbf{b}: 2.6 \times 10^{-6}\right.$, c: $3.9 \times 10^{-6}\left(\mathrm{~mol} \mathrm{~L}^{-1}\right)$ of the HPDMS).

Table II. Number of chromic compounds encapsulated by HPDMS

\begin{tabular}{lccccc}
\hline & {$[\mathrm{P}]^{\mathrm{a}}\left(\mathrm{mol} \mathrm{L}^{-1}\right)$} & $\mathrm{A}$ & $\mathrm{e}^{\mathrm{b}}$ & {$[\mathrm{C}]^{\mathrm{a}}\left(\mathrm{mol} \mathrm{L}^{-1}\right)$} & $n^{\mathrm{d}}$ \\
\hline & $1.3 \times 10^{-6}$ & 0.55 & & $7.7 \times 10^{-6}$ & 5.7 \\
1,6-Diphenylhexatriene & $2.6 \times 10^{-6}$ & 1.39 & $7.5 \times 10^{4}$ & $18.6 \times 10^{-6}$ & 6.9 \\
& $3.9 \times 10^{-6}$ & 1.65 & & $22.1 \times 10^{-6}$ & 5.5 \\
\hline \multirow{3}{*}{ Nitrotoluene } & $1.3 \times 10^{-6}$ & 0.15 & & $1.4 \times 10^{-5}$ & 10.0 \\
& $2.6 \times 10^{-6}$ & 0.30 & $1.1 \times 10^{4}$ & $2.7 \times 10^{-5}$ & 10.1 \\
& $3.9 \times 10^{-6}$ & 0.47 & & $4.3 \times 10^{-5}$ & 10.7 \\
\hline \multirow{3}{*}{ 1-Chloro- } & $1.3 \times 10^{-6}$ & 0.78 & & $2.1 \times 10^{-5}$ & 15.7 \\
2,4-nitrobenzene & $2.6 \times 10^{-6}$ & 1.41 & $3.7 \times 10^{4}$ & $3.8 \times 10^{-5}$ & 14.3 \\
& & & & & \\
& $3.9 \times 10^{-6}$ & 1.98 & & $5.4 \times 10^{-5}$ & 14.0 \\
\hline
\end{tabular}

${ }^{\mathrm{a}}$ Concentration of HPDMS in the acidic aqueous solution. ${ }^{\mathrm{b}}$ Molar absorption coefficient measured in the THF. ${ }^{\circ}$ Concentration of chromic compounds in the HPDMS acidic aqueous solution. ${ }^{\mathrm{d}} n=[\mathrm{C}] /[\mathrm{P}]$.

\section{1,6-diphenylhexatriene is larger than two ones.}

The contact angles of HPDMS contribute to infer micelle effect. Figure 4 shows droplets of the HPDMS aqueous solution placed on a Teflon ${ }^{\circledR}$ plate. The contact angle decreased dramatically in the $1.3 \times 10^{-6} \mathrm{~mol} \mathrm{~L}^{-1}$ solution of the HPDMS (a and $\mathbf{b}$ ), however, there are a little difference of angles in the $2.6 \times 10^{-6} \mathrm{~mol} \mathrm{~L}^{-1}$ and $3.9 \times 10^{-6} \mathrm{~mol} \mathrm{~L}^{-1}$ solutions.

\section{CONCLUSION}

We presented a new amphiphilic hyperbranched poly(dimethylsiloxanes) (HPDMS) having dimethylamino groups as hydrophilic end groups. The endcapped HPDMS showed good thermal properties and good solubility, similar to that of our previous report. In addition, the HPDMS was soluble in acidic aqueous 

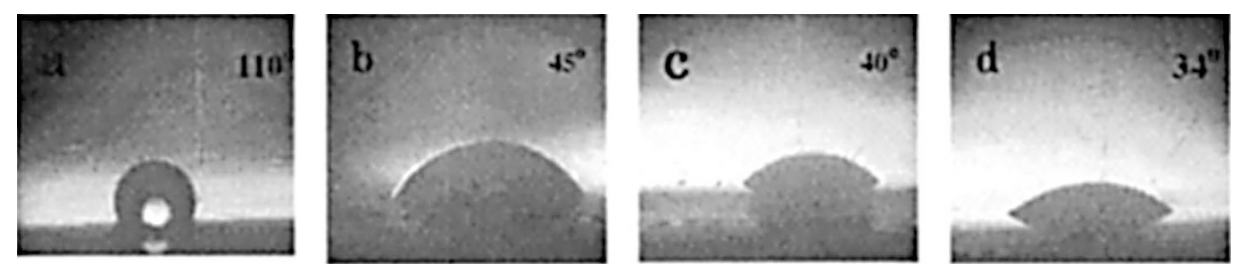

Figure 4. Contact angles of the HPDMS acidic aqueous solution on Teflon ${ }^{\circledR}$ (a :acid aqueous solution, $\mathbf{b}: 1.3 \times 10^{-6}, \mathbf{c}: 2.6 \times 10^{-6}, \mathbf{d}$ : $\left.3.9 \times 10^{-6}\left(\mathrm{~mol} \mathrm{~L}^{-1}\right)\right)$.

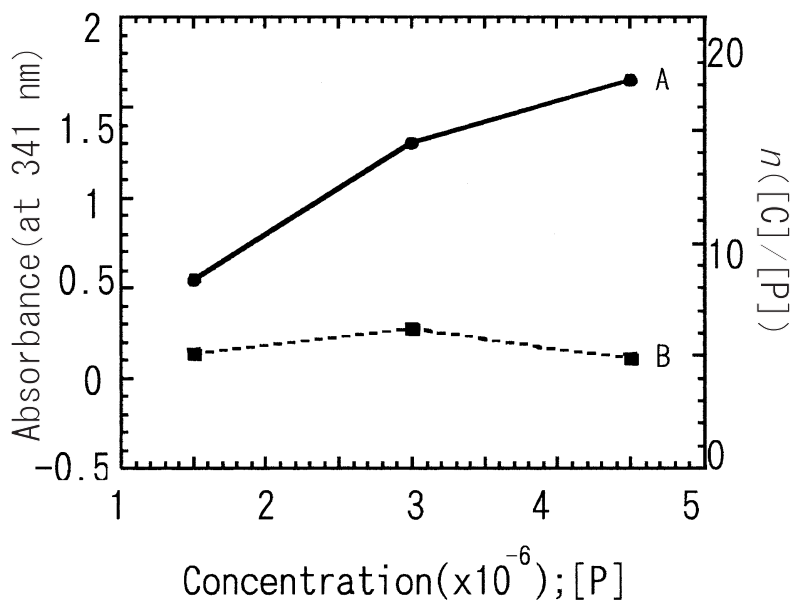

Figure 3. Effect of the concentration of HPDMS on the encapsulation of 1,6-diphenylhexatriene (A; absorbance at $341 \mathrm{~nm}$, $\mathrm{B} ;[\mathrm{C}] /[\mathrm{P}]$; number of the chromic compound encapsulated by a HPDMS).

solution. Encapsulation of hydrophobic chromophores by the HPDMS was confirmed by UV absorption spectroscopy. Invariable number of dissolved molecules in the range 5-14, determined by UV absorption implies encapsulation of hydrophobic chromophores by the HPDMS in acidic solution and the formation micelle.

Surface activating effect was also confirmed by the contact angle of the acidic solution of the HPDMS on to a Teflon ${ }^{\circledR}$ plate. It is clear that the HPDMS worked as a surface active agent and lowered the surface energy of the acidic solution.

\section{REFERENCES}

1. J. M. Zeigler, "Silicon-Based polymer Science", A comprehensive Resource, J. M. Zeigler, F. W. Fearon, Ed., American Chemical Society, Washington, D. C., 1990.

2. C. Burger, W. R. Hertler, P. Kochs, F. H. Kreuzer, H. R. Kircheldorf, R. Mulhaupt, in Silicon in Polymer Synthesis, H. R. Kircheldorf, Ed, Springer-Verlag, Washington, D.C., 1990.

3. S. J. Clarson, in "Siloxane Polymers", J. A. Senlyen, Ed., Englewood Cliff, N.J., 1993.

4. L. J. Mathias and T. W. Carothers, J. Am. Chem. Soc., 113, 4043 (1991).

5. a) A. M. Muzafarov, M. Golly, and M. Möller, Macromolecules, 28, 8444 (1995). b) A. M. Muzafarov, E. A. Rebrov, O. B. Gorbacevich, M. Golly, H. Gankema, and M. Möller, Macromol. Symp., 102, 35 (1996).

6. a) S. Rubinaztajn, J. Inorg. Organomet. Polym., 4, 61 (1994).

b) S. Rubinaztajn and J. Stein, J. Inorg. Organomet. Polym., 5, 43 (1995).

7. J. F. Miravet and J. M. J. Fréchet, Macromolecules, 31, 3461 (1998).

8. D. W. Van Krevelen, "Properties of Polymer 3rd.", Elsevier Science Publishers B.V., Amsterdam, 1990, chapt. 6.

9. L. J. Mathias and T. W. Carothers, J. Am. Chem. Soc., 113, 4043 (1991).

10. K. Matyjaszewski, H. Frey, M. Cypryk, J. Hrkach, K. H. Kim, M. Möller, K. Ruehl, and M. White, J. Macromol. Sci., Chem., 271, 55 (1991).

11. a) K. Matyjaszewski, H. Frey, and M. Möller, Colloid polym. Sci., 269, 442 (1991).

b) H. Frey and M. Möller, S. Sheiko, Colloid polym. Sci., 271, 554 (1993).

12. A. M. Muzafarov, M. Golly, and M. Möller, Macromolecules, 28, 8444 (1995).

13. A. M. Muzafarov, E. A. Rebrov, O. B. Gorbacevich, M. Golly, H. Gankema, and M. Möller, Macromol. Symp., 102, 35 (1996).

14. S. J. Rubinsztajn, J. Inorg. Organomet. Polym., 4, 61 (1994).

15. S. J. Rubinsztajn and J. Stein, J. Inorg. Organomet. Polym., 5, 43 (1995).

16. J. F. Miravet and J. M. J. Fréchet, Macromolecules, 31, 3461 (1998).

17. C. Gong, J. F. Miravet, and J. M. J. Fréchet, J. Polym. Sci., Part A: Polym. Chem., 37, 3193 (1999).

18. B. M. Disher, Y. Y. Won, D. S. Ege, J. C. Lee, F. S. Bates, D. E. Disher, and D. A. Hamer, Science, 284, 1143 (1999).

19. A. Morikawa, M. Kakimoto, and Y. Imai, Macromolecules, 24, 3469 (1991).

20. A. Morikawa, M. Kakimoto, and Y. Imai, Polym. J., 24, 573 (1992).

21. S. W. Shalaby, G. B. Butler, and C. L. McCormick, Ed., "Water-soluble Polymer: Synthesis, Solution Properties and Application", American Chemical Society, Washington, D.C., 1991.

22. G. R. Newkome, C. N. Moorfield, F. Vögtle, "Dendritic Molecules", VCH Publishers, Weinherim, Germany, 1996.

23. O. A. Mathews, A. N. Shipway, and J. F. Stoddart, Prog. Polym. Sci., 23, 1 (1998).

24. K. M. Kim, M. Jikei, and M. Kakimoto, Polym. J., 34, 275 (2002). 